\title{
DIE KONTINUITEIT VAN DIE KERK ONDER OU EN NUWE VERBOND.
}

Veral van Angelsaksiese kant word dikwels die uitspraak verneem dat die Kerk op die Pinksterfees te Jerusalem gestig is. Dit word gewoonlik as 'n vanselfsprekende waarheid gestel, en mense wat onvoldoende krities geskool is, is geneig dit dan ook te aanvaar. So hoor mens dit dan ook wel uit die mond van Afrikaanse teoloë wat beter tuis is in Engelse stigtelike lektuur as in die Skrif en die Belydenis. Een keer is hierdie bewering selfs in die Algemene Kerkvergadering van die 
Nederduits Hervormde Kerk van Afrika gemaak, maar daar het gelukkig onmiddellik 'n algemene protes teen hierdie kettery opgegaan.

Dat dit in stryd is met die belydenisskrifte van ons Kerk, kan nie betwyfel word nie. In art. XXVII van die Nederlandse Geloofsbelydenis heet dit uitdruklik: „Hierdie Kerk was daar van die begin van die wereld af en sal daar wees tot aan die einde toe, soos daaruit blyk dat Christus 'n ewige Koning is wat nie sonder onderdane kan wees nie. En hierdie heilige Kerk word deur God bewaar of in stand gehou teen die woede van die hele wêreld, alhoewel dit somtyds 'n tyd lank baie klein is en in die oë van die mense skynbaar tot niet geraak het. So het die Heer vir Hom gedurende die gevaarlike tyd onder Agab seweduisend mense bewaar wat hulle knieë voor Baäl nie gebuig het nie." Uit die deur ons kursief gedrukte passasies blyk dit duidelik dat die Nederlandse Geloofsbelydenis die Kerk se geskiedenis nie met Pinksterfees laat begin nie, maar ook die Ou Testamentiese tydvak daarby insluit.

Dieselfde vind ons in die Heidelbergse Kategismus. In Sondag XXI, vraag 53 lees ons : „Dat die Seun van God uit die ganse menslike geslag vir Hom 'n gemeente wat tot die ewige lewe uitverkies is, deur sy Gees en Woord, in die eenheid van die ware geloof, van die begin van die wereld af tot aan die einde toe vergader, beskerm en onderhou; en dat ek daarvan 'n lewende lid is en ewig sal bly." Ook hier het ons weer die woorde waarop dit vir ons in hierdie verband aankom, gekursiveer. In die Kategismusbundel „U enigste troos" wat onlangs onder redaksie van Ds. Joh. Dreyer die lig gesien het, lê Ds. D. F. Erasmus gelukkig baie nadruk daarop (p. 134, 135): „Maar wanneer ons vra na die ontstaan van die kerk in die tyd, moet ons antwoord dat dit daar was van die begin van die wêreld af; die eerste aanvange van die kerk op aarde lê in die paradys."

Selfs in die Dortse Leerreëls, wat tog oor heel ander dinge handel, vind ons nog iets van die erkenning van die eenheid van die Kerk deur Ou en Nuwe Verbond heen terug, as ons in hoofstuk III en IV, $\S 6$ lees: „Wat dus die lig van die natuur en ook die Wet nie kan doen nie, dit doen God deur die krag van die Heilige Gees deur middel van die Woord of die bediening van die versoening, wat die Evangelie van die Messias is waardeur dit God behaag het om die gelowige mense in die Oue sowel as in die Nuwe Testament salig te maak.

Aan die opvatting van die belydenisskrifte op hierdie punt kan dus nie getwyfel word nie. Maar in ' $n$ Reformatoriese gemeenskap het die belydenisskrifte nooit die laaste woord nie. Dit is altyd moontlik en dikwels noodsaaklik om van die belydenisskrifte terug te gaan op die Heilige Skrif. Daarom wil ons die vraag stel: wat leer die Bybel self oor die kontinuiteit van die Kerk onder Ou en Nuwe Verbond?

Hier kom ons terstond by 'n moeilikheid wat voortspruit uit 'n eienaardigheid van ons Bybelvertalings. Die woord Kerk is ons alge- 
meen aanvaarde vertaling van die Griekse woord ekklèsia, maar terwyl daardie Griekse woord volop in die Griekse Bybel teenkom, soek ons sy weergawe "Kerk" tevergeefs in die Afrikaanse Bybelvertaling. Dieselfde geld trouwens ook ten aansien van die Nederlandse Protestantse Bybelvertalings. Trommius se konkordansie ken alleen die woorde „,kerkbewaarster" (Hand. 19:35) en „,kerkrover" (Hand. 19:37). Tereg het die Afrikaanse vertaling in hierdie twee tekste die woorddeel "kerk" vervang deur "tempel": dit gaan op daardie plaatse oor 'n heidense instelling.

Die vermyding van die woord ",kerk" in die Bybelvertalings gaan vermoedelik terug op Luther, wat in sy vertaling stelselmatig die woord "Gemeinde" gebruik en die woord "Kirche" ontwyk het. Calvyn het hierdie vrees vir die woord "Kerk" nie geken nie en die Franse Bybzlvertalings gebruik dan ook onbevang z die woord ..église", wat t cuens 'n afleiding is van die Griekse woord ekklèsia. Die Nederlandse Geloofsbelydenis gebruik die woord Kerk volop: die Kategismus is op hierdie punt veel terughoudender. Die opvatting het ontwikkel dat "gemeente" die plaaslike vergadering van die Christene aandui, „Kerk" die geheel. Hierdie verskil word in die Skrif nie gevind nie. Die Skrif ken geen twee verskillende terme vir ,plaaslike gemeente" en ,algemene kerk" nie. Dit belet ons nie om tog daardie twee terme te gebruik nie: dis net 'n saak van terminologie.

Ons moet dus, wanneer ons die Bybel nalees oor die vraag na die begin van die Kerk, ons aandag nie op die woord, maar op die saak rig. Vind ons êrens aanwysings vir die bestaan van die Kerk voor die Pinksterfees?

Ons wil in hierdie verband nie, soos ander gedoen het, op passasies soos Rom. 4:9 vv. of Gal. 4:21 vv. wys nie. Hulle het geen regstreekse verband met ons onderwerp nie, aangesien hulle net spreek van die bedoelinge van die Outestamentiese openbaring, maar die aktuele Kerk nie vermeld nie. Netso skakel ons ook Ef. 1:3 vv. uit, want dit handel oor die ewige verkiesing, nie oor die Kerk as aardse grootheid nie.

Iets digter by ons doel kom ons deur Ef. 2:20, waar Paulus van die gemeente sê "gebou op die fondament van die apostels en profete". Ons sou dit so kan uitlê, dat hier die Kerk onderskei word na sy Outestamentiese en na sy Nutestamentiese verskyning; die profete staan vir die Outestamentiese tydvak, die apostels vir die Nutestamentiese. Maar teen hierdie eksegese kan ingebring word dat op twee ander plekke in dieselfde brief $(3: 5$ en $4: 11)$ die ..profete" kennelik as profete uit die Nutestamentiese tydvak verstaan moet word (vgl. Hand. 11:27; $21: 10)$.

Veel duideliker is ' $n$ trek wat telkens terugkom in die beskrywing van die hemelse heerlikheid in die Openbaring van Johannes. Sesmaal (Openb. 4:4, 10;5:8,14;11:16;19:4) word gepraat van vier en twintig ouderlinge. Hulle het die witte priestergewaad en die konink- 
like kroon: dus hulle is „,konings en priesters" (vgl. 1:6; 5:10; 5:20; ook I Petrus 2:9). Hierdie uitdrukking is ontleen aan die Ou Testament, en dui daarin die Godsvolk Israel aan: .Julle sal vir My 'n koninkryk van priesters en 'n heilige nasie wees" (Ex. 19:6). Maar die vier en twintig ouderlinge verteenwoordig meer as net die bondsvolk uit die ou bedeling; volgens hulle eie woorde (Openb. 5:9) het die Here Jesus hulle ,vir God met (sy) bloed gekoop uit elke stam en taal en volk en nasie". Met ander woorde ons het hier te doen met 'n simboliese aanduiding van die Kerk sowel onder die Ou as onder die Nuwe Verbond. Vandaar ook die getal vier en twintig: twaalf vir die Godsvolk uit die Outestamentiese tyd met sy twaalf aartsvaders en twaalf stamme; twaalf ook vir die nuwe Godsvolk, byeengebring deur die prediking van die twaalf apostels (vgl. ook Jakobus 1:1). Daarmee korrespondeer dan ook die skare van die verlostes uit $h$ fst. 7 : honderd vier en veertig duisend uit Israel, en daarlangs ,.'n groot menigte wat niemand kon tel nie, uit alle nasies en stamme en volke en tale."

Hier sien ons dus duidelik die eenheic van die Kerk onder die twee bedelinge: daar word onderskeid gemaak, maar daar vind geen skeiding plaas nie. Die werk van aanbidding en verheerliking, van belydenis en martelaarskap, is een en ongedeel.

Dieselfde boek Openbaring gee ons nog ' $n$ ander aanwysing. In die twaalfde hoofstuk beskrywe die apostel vir ons 'n visioen, waarin hy in die hemel 'n vrou sien ,wat met die son bekleed was, en die maan was onder haar voete, en op haar hoof 'n kroon van twaalf sterre". Hierdie vrou baar 'n kind ,wat al die nasies met 'n ystersepter sou regeer; en haar kind is weggeruk na God en sy troon." Die vrou is teen die aanvalle van 'n draak deur God beskerm; haar ander nakomelinge "wat die gebooie van God bewaar en die getuienis van Jesus Christus hou" word deur die draak belaag.

Die beskrywing van die Kind pas duidelik op die Here Jesus. Is die vrou dan Maria? Die Roomse Kerk het dit dikwels beweer, en daar is heelwat afbeeldings in Roomse kerkgeboue wat Maria so voorstel. Maar hierdie uitleg is onhoudbaar. Die beskrywing van haar „ander nakomelinge" toon duidelik dat sy die Kerk is. As dit so is, dan volg daaruit dat hierdie hoofstuk van die Here Christus sê dat Hy gebore is in die Kerk. Dit was reeds daar, toe die Here op aarde verskyn het. Na sy mensheid is die Here ' $n$ lid van die gemeente van die Ou Verbond. So blyk dus ook hier die eenheid van die Kerk deur Ou en Nuwe Verbond.

Nog verder kan ons gaan as ons let op Rom. $11: 13-32$. Daar word die bekering van die heidene tot die Evangelie beskryf as die inenting van wilde takke in die mak olyfboom Israel. Met ander woorde, die Kerk is nie 'n nuwe stigting nie: in wese is dit nie anders as die ou Godsvolk, al is dit dan ook dat 'n aantal takke afgebreek is. K₹nmerkend in hierdie verband is dat die apostel in verband met die toebrenging van die heidene die woord ,ingaan" gebruik. Waartoe gaan 
die heidene in? Tot die reeds bestaande gemeenskap van die volk van God, die Kerk.

Die heidene wat Christus aanneem het daarmee volberegtigde lede van die reeds bestaande Kerk geword. Vandaar dat dit in Ef. 2:19 heet: "So is julle dan nie meer vreemdelinge en bywoners nie, maar medeburgers van die heiliges en huisgenote van God." Hier blyk dit opnuut duidelik dat daar reeds ' $n$ Kerk bestaan het. Die toevloei van die heidene beteken nie die stigting van 'n nuwe Kerk nie, maar die inlywing in die gemeenskap wat van ouds bestaan het. Deur die geloof word mens medeburger van die Godsvolk waarvan die geskiedenis in die Ou Testament beskryf is. So heet dit ook in I Petrus 2:10, met n duidelike sinspeling op Hosea 2:22: ,julle wat vroeër geen volk was nie, maar nou die volk van God is; aan wie toe geen barmhartigheid bewys is nie, maar nou bewys is."

Hier sien ons hoe die Kerk onder die nuwe bedeling "die volk van God" genoem kon word. Die naam self hou vas aan die eenheid tussen Israel en die gemeente van die Nuwe Verbond. In dieselfde rigting wys party ander benamings van die Kerk in die Nuwe Testament. Dit word genoem „,die Israel van God" (Gal. 6:16), wat temeer betekenis het omdat die naam juis voorkom in 'n passasie en in 'n brief waarin die volle nadruk gelê word op die nuwe wat in Christus verskyn het. Uit die uitdrukking "Israel na die vlees" (I Kor. 10:18) kan mens aflei dat die Nutestamentiese gemeente hom "Israel na die gees" gevoel het, en dat dit hom self as die geestelike, legitieme voortsetting van die Outestamentiese Israel beskou het. So moet ons ook die benaming "nageslag van Abraham" (Gal. 3:29) verstaan, en netso ook die aanduiding "die vreemdelinge van die verstrooiing" (I Petrus 1:1), waarmee nie gesê is dat die lesers van die brief vreemdelinge in Jerusalem is nie, maar inteendeel burgers van Israel wat as vreemdelinge orals verstrooid in Pontus, Galasië en ander landstreke vertoef. Burgers van Israel: nie omdat hulle gebore Israeliete is nie - 2:10 bewys dat die lesers Christene uit die heidene is - maar omdat hulle as lidmate van die Kerk lede van die Godsvolk is.

Behalwe hierdie tekste uit die Nuwe Testament is daar nog meer algemene taalkundige oorwegings wat ons moet laat besluit dat die belydenisskrifte reg is as hulle die oorsprong van die Kerk ver voor die Pinksterfees soek. Die woord ekklèsia, wat in die ou belydenisse altyd met "Kerk" weergegee word, het 'n tweevoudige geskiedenis. Aan die een kant is dit deur die heidense Grieke gebruik as aanduiding van die wettige vergadering van die volle burgers van 'n stad; aan die ander kant vind ons dit in die ou Griekse vertalings van die Ou Testament as weergawe van die Hebreeuse woord qahal, wat in ons Bybelvertaling vertolk is met "vergadering". Dit is gewoonlik die aanduiding van die volksvergadering van Israel, sowel na sy religieuse as na 
sy staatkundige kant. Vir die ore van die Grieks sprekende Jode het die benaming ekklèsia vir die gemeente van die Nuwe Testament dus geklink as 'n aanduiding, dat hierdie gemeente die voortsetting is van die qahal van ou Israel. Deurdat die gemeente homself ekklèsia noem, handhaaf dit die eenheid van die Godsvolk onder die Oue en die Nuwe Verbond.

Dit kom nog duideliker tot uiting, as ons let op die feit dat in die boeke Genesis, Exodus, Levitikus en Numeri die woord qahal deur die Griekse vertalers nie met ekklèsia vertolk word nie, maar met sunagoogè, wat ons woord „synagoge" is. Met ander woorde die Kerk, die ekklèsia, se naam gaan op dieselfde Outestamentiese begrip terug as die sinagoge! So verstaan ons ook dat die woord sinagoge een keer in die Nuwe Testament gebruik word as aanduiding van die Christelike byeenkoms : in Jak. 2:2 (Afrikaanse vertaling: „vergadering”). Dieselfde skrywer gebruik elders $(5: 14)$ die woord ekklèsia (Afrikaanse vertaling: .,gemeente").

Hierdie woordgebruik het dus 'n polemiese spits: die gemeente sê: ons is die ware qahal, die ware sinagoge. So skrywe die apostel Paulus dan ook (Filipp. 3:3): ..Want ons is die besnydenis, ons wat God in die Gees dien en in Christus Jesus roem en nie op die vlees vertrou nie". Teenoor die teenstanders van die apostel hou ons saam met hom vas aan die gedagte dat die Kerk die wettige voortsetting is van die verbondsvolk uit vroeër eeue, of liewer nog, dat die Kerk die gestalte van 'n volk gehad het tot die koms van Christus, en dat dit vervolgens na die beloftes van die Ou Testament self (bv. Jes. 49:6) hom oor al die volke uitgebrei het.

Daar kan ook meer algemene oorwegings te berde gebring word. Die Kerk wortel in die werklikheid van die verbond wat God met die mens aangegaan het. Die verbond $k a n$ in die loop van die tyd verskillende gestaltes aanneem, maar die inhoud daarvan bly in wese dieselfde. As ons die verbond met Israel en die verbond met die $\mathrm{Nu}$ testamentiese gemeente met mekaar vergelyk, tref ons belangrike punte van ooreenkoms. Om maar in paar op te som : dit is unilateraal: dws. dit gaan van God alleen uit; God roep mense op om in sy verbond te staan. Dis merkwaardig en veelseggend dat die stam van qahal sowel as van ekklèsia afgelei word van woorde wat „om te roep" beteken. Verder berus die verbond in altwee gevalle op die barmhartigheid van God, wat die sonde vergewe nie op grond van menslike prestasie nie. maar alleen van uit die diepte van sy eie ontferming. Ook stel die verbond sowel aan die Godsvolk in die ou dae as aan die gemeente in die nuwe bedeling die eis van liefde en geregtigheid. Dit rig hom sowel tot die gemeente as in geheel as ook tot ieder lidmaat daarvan in die besonder, en verenig sodoende die skynbaar teengestelde begrippe van kollektivisme en persoonlikheid. Dit is sterk op die toekoms gerig, en 
moet dus esgatologies genoem word, dws. dit bereik sy volmaking eers in die ewigheid. In die middelpunt van die heil staan die gestalte van die Messias. Die ou en die nuwe Verbond is een in geloof, hoop en liefde.

Van hieruit kan ook die vraag beantwoord word of die Kerk dan miskien begin op die oomblik van die verbondsluiting op die Sinai. Dit is seker nie die geval nie. Die Ou Testament lê nadruk daarop dat die God van Moses die God van die vaders is. By sy roeping kry Moses die opdrag om vir sy volk te sê: „Die Here, die God van julle vaders, het aan my verskyn, die God van Abraham, Isak en Jakob." Daar was reeds 'n verbond voordat die nuwe gestalte by die Sinai sy beslag gekry het.

Vra ons dan, hoever ons terug kan gaan, dan kom ons uit by die Paradys. Die verbond is daar op die oomblik dat 'n genadige God uit barmhartigheid aan 'n gevalle mensheid die vergewing van die sondes verkondig. Met ander woorde, die verbond begin met Gods soekende liefde na die val van die eerste mens. In die teks wat die Kerk tereg die protevangelie, die eerste blye boodskap, genoem het, in Gen. 3:15, het ons die stigtingswoorde van die verbond. Dis die aankondiging van stryd tussen die vrouesaad en slangesaad, tussen die mens en die bose, met die belofte van uiteindelike oorwinning aan die nageslag van die vrou. Hierin is alles reeds aangekondig: die vergewing uit genade, die eis van geregtigheid en liefde, die binding sowel van individu as van kollektiviteit, die rigting na die toekoms, en die belofte van die Messias

Dit is fraai uitgedruk deur die Nederlandse Geloofsbelydenis, wat in art. XVII verklaar: „Ons glo dat onse goeie God, nadat Hy gesien het dat die mens homself in die liggaamlike en geestelike dood gewerp en geheel-en-al ellendig gemaak het, deur sy wonderlike wysheid en goedheid die mens, toe hy al bewende van Hom weggevlug het, weer opgesoek en getroos het, met die belofte om hom sy Seun te gee wat uit 'n vrou gebore sou word om die kop van die slang te vermorsel en hom geluksalig te maak." Hier is die begin van die Kerk. Dit lewe uit daardie soekende en troostende liefde, wat in Christus vlees en bloed geword het, maar wat altyd die beginsel van die verkeer van God met sondaars was. Sodoende kan ons sê dat die gelowiges van die $\mathrm{Ou}$ Testament nie op 'n ander manier salig geword het as ons nie.

Verder terug mag ons nie gaan nie. As soos aangehaal die Nederlandse Geloofsbelydenis in art. XXVII sê dat die Kerk daar was „van die begin van die wêreld af", dan moet dit verstaan word as betekenende "van die begin van die wêreld soos ons dit nou ken af", dws. van die begin van die gevalle wêreld af. So word dit sowel deur A. Kuyper ( $E$ voto Dordraceno, op antwoord 54 van die Kategismus) as deur Th. L. Haitjema (Dogmatiek als apologie, 1948, p. 281, 282) verstaan. Die Kerk was altyd die gemeenskap van sondaars, wat deur God tot sy genade geroep is. 
Ons gaan dus nie verder terug as tot die begin van die menslike geskiedenis nie. Daar was nooit 'n sondelose Kerk nie. Maar ons stel daar prys op om te behoor tot dié gemeenskap, wat deur God in sy genade onmiddellik na die sondeval onder sondige mense tot stand gebring is. So goed as die Nederduits Hervormde Kerk van Afrika hom nooit sy band met die Kerk van Van Riebeeck en die Kerk van Willebrord sal laat ontstry nie, netso goed hou ons soos die Apostels die band met Israel en die patriarge van voor Israel vas.

A. VAN SELMS. 